\title{
Merchant Banking Operation: A Case Study of Selected Merchant Banks in Bangladesh
}

\author{
Farzana Huda (Corresponding Author) \\ Senior Lecturer, Department of Business Administration \\ East West University \\ A/2 Jahirul Islam City, Aftabnagar, Dhaka 1212, Bangladesh \\ E-mail:farjana_huda@yahoo.com \\ Professor Dr. Tanbir Ahmed Chowdhury \\ Dean, Faculty of Business and Economics \\ East West University \\ A/2 Jahirul Islam City, Aftabnagar, Dhaka 1212, Bangladesh \\ E-mail: tanbir@ewubd.edu
}

\begin{abstract}
Received: April 22, $2016 \quad$ Accepted: February 22, $2017 \quad$ Published: June 1, 2017
doi:10.5296/ajfa.v9i1.10712 URL: https://doi.org/10.5296/ajfa.v9i1.10712
\end{abstract}

\begin{abstract}
In Bangladesh the establishment of merchant bank added value to the stock market which plays a vital role in the progress of economic development. This study tried to analyze the performance of Lanka Bangla Investment Ltd., Prime Finance Capital Management Ltd., IDLC Investment Ltd. and Uttara Finance and Investment Ltd. Seven trend equations have been tested for different activities of the selected merchant banks. It is observed that the selected merchant banks were able to achieve a stable growth of investment in securities, margin loan to clients, brokerage commission, capital gain/loss from securities, portfolio management services, issue management fees, corporate advisory fees and underwriting commission during the period of 2011-2015. Among them the trend equation of investment in securities, margin loan to clients, and corporate advisory fees are positive incase of all the selected merchant banks. Square of correlation coefficient $\left(r^{2}\right)$ has also been tested for all trend equations. The $r^{2}$ of interest income from merchant bank, portfolio management
\end{abstract}




\section{Macrothink}

Asian Journal of Finance \& Accounting ISSN 1946-052X 2017, Vol. 9, No. 1

services, settlement and transaction fees and documentation fees, is more than 0.5 . It indicates the prospect of merchant banks in Bangladesh is bright.

Keywords: Merchant bank, Underwriter, Brokerage commission 


\section{Introduction}

The capital market is an intermediation through which the surplus money of the society can be mobilized and channeled into productive investments with the eventual aim of fostering development of the country's economy. Merchant banks contributes greatly for the development of more authenticated and structured capital market and helps to form a more stable economy. It helps to serve the nation by generating production, employment and earning foreign currency as well as improving the foundation of capital market through equity investment participation. The core business of merchant banking comprises management services, portfolio management services and underwriting services.

In Bangladesh, new entrepreneurs are facing acute shortage of capital. There is not a single investment bank in the country which could provide direct equity funds to the entrepreneurs and in that situation merchant banks play the role of investment banks. Merchant banks play major roles in listing securities with stock exchanges. It integrates fund for entrepreneurs in many ways like Initial Public Offering (IPO), Repeat Public Offering (RPO), Rights Share Offer, and Direct Listing for selling of existing paid-up capital, issue of preference share, convertible or non-convertible in shares.

Investor confidence is a prerequisite for the growth and development of the securities market. Through the regulations and guidelines of SEC to Merchant Bank, issuer can raise their resources at low cost, effectively and easily, ensure a high degree of protection of the interests of the investors and provide a dynamic and competitive market with high standard of professional competence, honesty, integrity and solvency. The regulations promote a fair, efficient, and flexible capital market.

\section{Literature Review}

Animesh (2016) investigated that Globalization of Indian Economy has made the whole economy open, which has move multinational player in era of the financial services. Government has now open up the doors of investments especially in the area of banks and insurance which leads to competitive environment for the present players. The study also revealed that in India, at present, a substantial number of Merchant Bankers are operating under the direct supervision of Securities and Exchange Board of India (SEBI) and also evaluated the performance of selected Merchant Bank of India.

Nayak (2015) inspected that formal merchant banking activity in India was originated in 1969 with Merchant Banking Division set up by the Grindlays Bank. He point out that the main service offered at that time to the corporate enterprises by the merchant banks included the management of public issues and some aspects of financial consultancy. The early and mid-seventies witnessed a boom in the growth of merchant banking organizations in the country with various commercial banks, financial institutions and broker's firms entering in to the field of merchant banking.

Shreyas (2014) focused on the overall view of merchant banking in past as well as present with respect to India. The study revealed that Merchant banking is one of the oldest and specialized financial intermediaries in the primary market and its activity has developed 
rapidly in the Indian capital market with more than 1450 merchant bankers and more than 930 has registered with SEBI. Merchant banking in India has a very bright future in the coming years and has all potential in competing with International countries.

Biswajit and Pranab (2012) examined that merchant banking is a much desired innovative step undertaken by the commercial banks in India. The study focused that the need for merchant banking was strained by the Banking Commission (1972) and according to the commission, merchant banking institutions are to offer fund based on non-fund based services like syndication of financing, promotion of projects, investment, management and advisory services to medium and small savers and to provide funds and trusts to various types etc. Their main function is to guide the preparation, planning, evaluation and execution of projects which are helpful to the growth of industries.

Anand (2009) explored privatization and globalization has become watch words today. The Government of India has adopted the new liberalized economic policy from July 1991 and one of the main agendas of the new policy is banking reforms. In this process of reforms the importance of Merchant Banking should not be neglected. The whole banking system in India and abroad is bound to change in the second millennium. Merchant banking cannot be an exception.

Sufian and Majid (2007) examined the efficiency changes of Malaysian Non-Bank Financial Institutions (NBFIs), during the period of 2000-2004, by applying the non-parametric Data Envelopment Analysis (DEA) method which allows to distinguish between three different types of efficiencies such as technical, pure technical and scale efficiency.

Kohn (1999) examined that the evolution of merchant banks which specialized in remittance and credit and their sources of funds and the fund usage to which they put them in exchange trading, commercial credit, and sovereign lending. The study also discussed the methods the banks used to manage liquidity and risk and the crisis that resulted from sovereign defaults.

Erik (1999) analyzed the demise of merchant banking by considering the impact of globalization on the historical banking institutions; the pace of innovation and the necessity for securities; the transformation of domestic industry into financial supermarkets; and the reason that UK clearing banks failed in their attempts to become international players.

Michael (1995) studied that merchant banking within the sane country may cover a wide range of activities in process include a number of a different financial institutions. A merchant banker has been defined under the security and exchange board of India rules 1992 as any person who is engaged in the business of issue management either by making arrangement regarding buying, selling, or subscribing to securities as manger, consultant, advisor or rendering corporate advisory services in relation to such issue management.

\section{Objectives of the Study}

- To present an overview of Merchant bank of Bangladesh.

- To appraise the activities of Merchant bank. 
- To appraise the performance of selected Merchant banks of Bangladesh.

- To recommend remedial measures for the development of selected Merchant banks of Bangladesh.

\section{Scope and Methodology of the Study}

The study has been carried out mostly on the basis of secondary data to evaluate the performance of selected Merchant banks of Bangladesh. The selected Merchant banks are LankaBangla Investment Limited (LBIL), Prime Finance Capital Management Limited(PFCML), IDLC Investment Limited(IDLCIL) and Uttara Finance and Investment Limited(UFIL). Others relevant data and information has been extracted from Stock Exchanges, Annual Reports of different merchant banks of Bangladesh, Bangladesh Securities and Exchange Commission and web sites of relevant merchant banks of Bangladesh etc. The study also incorporates existing literature and relevant articles on the performance of merchant bank. This article analyzed five years data i.e 2011-2015 of selected Merchant banks of Bangladesh. For evaluating the performance of selected Merchant banks of Bangladesh data has been analyzed through the various statistical measures like growth percentage, trend equation, square of correlation coefficient etc.

\section{Performance Evaluation of Selected Merchant Banks of Bangladesh}

This section evaluates the activities, development and prospect of selected merchant banks from year 2011 to 2015. In esteem to this analysis various variables i.e. investment in securities, margin loan to clients, brokerage commission, capital gain/loss from securities, portfolio management services, issue management fees, corporate advisory fees and underwriting commission and their growth percentage has been considered to evaluate the performance of selected merchant banks in Bangladesh. This study also measured the trend equations and $\mathrm{r}^{2}$ for the different mentioned variables.

\subsection{Investment in Securities}

Table: 1 showed growth pattern of investment in securities of selected merchant banks. It is observed from the table that investment in securities is highest in UFIL that is Tk. 823.84 million in 2014. The growth percentage of LBIL is highest in 2014 is $552.55 \%$. In 2015 growth percentage of LBIL and UFIL decreased to $36.49 \%$ and $17.17 \%$. The lowest growth percentage of investment in securities is in LBIL 2011. During 2011 to 2015 every year investment in securities of all selected merchant banks has increased but at a yearly decreasing rate. So it is reflected from the table that the investment in securities of all selected merchant banks has shown up and down trends during the period of 2011-2015. 


\section{Macrothink}

Table 1. Investment in Securities

BDT Million

\begin{tabular}{lrrrrr}
\hline Company & 2011 & 2012 & 2013 & 2014 & \multicolumn{1}{c}{2015} \\
\hline LBIL & 151.27 & 53.44 & 49.88 & 325.46 & 206.70 \\
Growth (\%) & -- & $(64.68)$ & $(6.66)$ & 552.55 & $(36.49)$ \\
PFCML & 292.94 & 374.34 & 245.56 & 273.45 & 375.13 \\
Growth (\%) & -- & 27.79 & $(34.40)$ & 11.35 & 37.19 \\
IDLCIL & 152.48 & 36.62 & 218.95 & 410.08 & 437.31 \\
Growth (\%) & -- & $(75.99)$ & 497.97 & 87.30 & 6.64 \\
UFIL & 2.10 & 0.96 & 207.57 & 823.84 & 682.40 \\
Growth (\%) & -- & $(54.39)$ & 21.55 & 296.90 & $(17.17)$ \\
\hline
\end{tabular}

Source: Author's calculation using the different issues of Annual Report of LankaBangla Investment Ltd., Prime Finance Capital Management Ltd., IDLC Investment Ltd. and Uttara Finance and Investment Ltd.

Note: US \$1 = BDT 78

\subsection{Margin Loan to Clients}

The growth patterns of Margin Loan to Clients of selected merchant banks of Bangladesh are revealed from Table: 2. It is depicted from the table that every year Margin Loan to Clients of selected merchant banks have increased from previous year. The growth of Margin Loan to Clients is more than 6\% in LBIL, PFCML and UFIL during 2012 to 2013. The lowest growth observed in PFCML. The growth percentage of Margin Loan to Clients of IDLCIL in 2014 is very high. Margin Loan to Clients of LBIL and PFCML decreased from year 2014 to 2015. 
Table 2. Margin Loan to Clients 2017, Vol. 9, No. 1

BDT Million

\begin{tabular}{lrrrrr}
\hline Company & 2011 & 2012 & 2013 & 2014 & 2015 \\
\hline LBIL & 3911.64 & 4160.44 & 4646.26 & 4262.86 & 3559.65 \\
Growth (\%) & -- & 6.36 & 11.68 & $(8.25)$ & $(16.50)$ \\
PFCML. & 2926.98 & 3231.95 & 8195.72 & 7134.51 & 3616.25 \\
Growth (\%) & -- & 10.42 & 153.58 & $(12.95)$ & $(49.31)$ \\
IDLCIL & 327.307 & 0 & 91.145 & 29.622 & 33.74 \\
Growth (\%) & -- & 0 & 0 & 32399.92 & 13.90 \\
UFIL & 1333.73 & 1409.65 & 1586.81 & 1761.58 & 1994.85 \\
Growth (\%) & -- & 5.69 & 12.57 & 11.01 & 13.24 \\
\hline
\end{tabular}

Source: Author's calculation using the different issues of Annual Report of LankaBangla Investment Ltd., Prime Finance Capital Management Ltd., IDLC Investment Ltd. and Uttara Finance and Investment Ltd.

Note: US $\$ 1=$ BDT 78

\subsection{Brokerage Commission}

Table: 3 showed that during 2011 to 2015 brokerage commission of all selected merchant banks have up and down growth trend. Brokerage commission of PFCML increased to TK.7,417,931 in year 2015 from year 2014. Brokerage commission of UFIL reached in highest peak in year 2014 i.e $18.62 \%$. On the other hand brokerage commission of LBIL and IDLCIL has positive growth rate in year 2014 i.e $41.64 \%$ and $24.94 \%$. 


\section{Macrothink}

Table 3. Brokerage Commission

BDT Million

\begin{tabular}{lrrrrr}
\hline Company & 2011 & 2012 & 2013 & 2014 & 2015 \\
\hline LBIL & 758.51 & 475.12 & 477.10 & 675.78 & 560.59 \\
Growth (\%) & -- & $(37.36)$ & 0.42 & 41.64 & 17.04 \\
PFCML & 0.062 & 0.44 & 0.51 & 0.32 & 7.42 \\
Growth (\%) & -- & 602.24 & 16.23 & $(37.91)$ & 2249.99 \\
IDLCIL & 206.986 & 163.53 & 149.46 & 186.73 & 216.03 \\
Growth (\%) & -- & $(20.99)$ & $(8.61)$ & 24.94 & 15.69 \\
UFIL & 57.16 & 31.23 & 23.97 & 28.44 & 17.72 \\
Growth (\%) & -- & $(45.37)$ & $(23.23)$ & 18.62 & $(37.70)$ \\
\hline
\end{tabular}

Source: Author's calculation using the different issues of Annual Report of LankaBangla Investment Ltd., Prime Finance Capital Management Ltd., IDLC Investment Ltd. and Uttara Finance and Investment Ltd.

Note: US $\$ 1=$ BDT 78

\subsection{Capital Gain/ (Loss) from Sale of Securities}

It is observed from the Table: 4 that during 2007 to 2011 capital gain/ (loss) from sale of securities of all selected merchant banks have increased from previous year. In most of the years capital gain/ (loss) from sale of securities have increased by more than $30 \%$. The capital gain/ (loss) from sale of securities of LBIL reached to Tk. 406.18 million in year 2013. The capital gain/ (loss) from sale of securities of IDLCIL showed a decreasing trend in year 2012 and 2014. 
Table 4. Capital gain/ (loss) from Sale of Securities

BDT Million

\begin{tabular}{lrrrrr}
\hline Company Name & 2011 & 2012 & 2013 & 2014 & 2015 \\
\hline LBIL & 9.76 & 32.98 & 406.18 & 38.62 & 72.47 \\
Growth (\%) & -- & 237.94 & 1131.72 & $(90.49)$ & 87.66 \\
PFCML & 14.73 & 59.61 & 85.36 & 110.48 & 18.80 \\
Growth (\%) & -- & 304.77 & 43.19 & 29.44 & $(82.99)$ \\
IDLCIL & $(101.58)$ & 4.74 & 29.30 & $(16.86)$ & 0 \\
Growth (\%) & -- & $(104.67)$ & 517.62 & $(157.53)$ & 0 \\
UFIL & 61.39 & 0 & 10.93 & 83.26 & 86.87 \\
Growth (\%) & -- & 0 & 0 & 661.96 & 4.33 \\
\hline
\end{tabular}

Source: Author's calculation using the different issues of Annual Report of LankaBangla Investment Ltd., Prime Finance Capital Management Ltd., IDLC Investment Ltd. and Uttara Finance and Investment Ltd.

Note: US $\$ 1=$ BDT 78

\subsection{Interest Income from Merchant Bank Activities}

Table: 5 showed that during 2011 to 2015 interest income from merchant bank activities of all selected merchant banks have decreased from previous year. Interest Income from merchant bank activities of PFCML and UFIL have increased by more than 20\% during 2014 to 2015 . Interest Income from Merchant Bank activities was peaked in 2011 of LBIL.

Table 5. Interest Income from Merchant Bank Activities

BDT Million

\begin{tabular}{lrrrrr}
\hline Company & 2011 & 2012 & 2013 & 2014 & 2015 \\
\hline LBIL & 716.81 & 624.72 & 571.36 & 165.05 & 109.48 \\
Growth (\%) & -- & $(12.85)$ & $(8.54)$ & $(71.11)$ & $(33.67)$ \\
PFCML & 473.51 & 328.40 & 163.29 & 234.12 & 286.27 \\
Growth (\%) & -- & $(30.65)$ & $(50.28)$ & 43.38 & 22.27 \\
IDLCIL & 67.64 & 86.18 & 103.89 & 82.03 & 74.30 \\
Growth (\%) & -- & 27.40 & 20.55 & $(21.04)$ & $(9.41)$ \\
UFIL & 205.01 & 207.64 & 67.85 & 94.98 & 106.28 \\
Growth (\%) & -- & 1.28 & $(67.32)$ & 39.98 & 11.89 \\
\hline
\end{tabular}




\section{Macrothink}

Source: Author's calculation using the different issues of Annual Report of LankaBangla Investment Ltd., Prime Finance Capital Management Ltd., IDLC Investment Ltd. and Uttara Finance and Investment Ltd.

Note: US $\$ 1=$ BDT 78

\subsection{Portfolio Management Services}

It is observed from Table: 6 that portfolio management services of all selected merchant banks attained high in year 2011 but after that it is decreasing during 2012 to 2015 . The highest growth rate observed in IDLCIL is $25.22 \%$ in 2014 . The portfolio management services of LBIL, PFCML and UFIL were not stable during 2012 to 2015. In 2015 portfolio management services increased to $14.94 \%$ growth in PFCML from the previous year but portfolio management services has decreased during 2012 and 2014 of most of the companies.

Table 6. Portfolio Management Services

BDT Million

\begin{tabular}{lrrrrr}
\hline Company & 2011 & 2012 & 2013 & 2014 & 2015 \\
\hline LBIL & 129.43 & 68.61 & 41.75 & 34.02 & 2312 \\
Growth (\%) & -- & $(6.99)$ & $(39.15)$ & $(18.52)$ & $(32.05)$ \\
PFCML & 146.69 & 99.63 & 84.94 & 60.68 & 69.74 \\
Growth (\%) & -- & $(32.08)$ & $(14.74)$ & $(28.57)$ & 14.94 \\
IDLCIL & 51.44 & 94.47 & 60.25 & 75.45 & 67.79 \\
Growth (\%) & -- & 83.64 & $(36.23)$ & 25.22 & $(10.15)$ \\
UFIL & 33.41 & 21.48 & 17.41 & 17.15 & 10.94 \\
Growth (\%) & -- & $(35.70)$ & $(18.95)$ & $(1.50)$ & $(36.20)$ \\
\hline
\end{tabular}

Source: Author's calculation using the different issues of Annual Report of LankaBangla Investment Ltd., Prime Finance Capital Management Ltd., IDLC Investment Ltd. and Uttara Finance and Investment Ltd.

Note: US \$1 = BDT 78

\subsection{Settlement and Transaction Fees}

Table: 7 showed growth pattern of settlement and transaction fees of selected merchant banks of Bangladesh. The table reflected that the growth of settlement and transaction fees of all the selected merchant banks were very unstable every year. In LBIL settlement and transaction fees growth rate was $37.87 \%$ and $10.38 \%$ in year 2012 and 2013 but suddenly decreased to $2.60 \%$ and $7.09 \%$ in year 2014 and 2015 . The growth pattern of IDLCIL and UFIL was quite unstable compared to LBIL. 
Table 7. Settlement and Transaction Fees

BDT Million

\begin{tabular}{lrrrrr}
\hline Company Name & 2011 & 2012 & 2013 & 2014 & 2015 \\
\hline LBIL & 25.15 & 34.66 & 38.26 & 37.27 & 34.62 \\
Growth (\%) & -- & 37.87 & 10.38 & $(2.60)$ & $(7.09)$ \\
PFCML & 0 & 0 & 0 & 0.003 & 0 \\
Growth (\%) & -- & 0 & 0 & 0 & 0 \\
IDLCIL & 10.93 & 34.15 & 22.08 & 26.24 & 21.65 \\
Growth (\%) & -- & 212.38 & $(35.34)$ & 18.85 & $(17.49)$ \\
UFIL & 23.27 & 0.12 & 0.42 & 0.35 & 0.24 \\
Growth (\%) & -- & $(99.47)$ & 237.81 & $(16.02)$ & $(29.24)$ \\
\hline
\end{tabular}

Source: Author's calculation using the different issues of Annual Report of LankaBangla Investment Ltd., Prime Finance Capital Management Ltd., IDLC Investment Ltd. and Uttara Finance and Investment Ltd.

Note: US \$1 = BDT 78

\subsection{Documentation Fees}

The growth patterns of documentation fees of selected merchant banks of Bangladesh are revealed from Table: 8 . It is depicted from the table that every year documentation fees of IDLCIL have increased from previous year and in year 2014 it reached in highest growth rate that is $94.34 \%$. On the other hand documentation fees of LBIL were high in 2014 that is TK.0.10 million. The growth pattern of documentation fees of PFCML has experienced a negative trend. The lowest growth observed in UFIL in year 2012. 


\section{1) Macrothink}

Table 8. Documentation Fees

BDT Million

\begin{tabular}{lrrrrr}
\hline Company & 2011 & 2012 & 2013 & 2014 & 2015 \\
\hline LBIL & 0.05 & 0.01 & 0.006 & 0.10 & 0.026 \\
Growth (\%) & -- & $(74.29)$ & $(55.56)$ & $(1591.67)$ & $(74.38)$ \\
PFCML & 0.04 & 0.04 & 0.014 & 0.012 & 0 \\
Growth (\%) & -- & $(14.29)$ & $(61.11)$ & $(14.29)$ & 0 \\
IDLCIL & 0.02 & 0.03 & 0.026 & 0.051 & 0.066 \\
Growth (\%) & -- & 11.11 & 6.00 & 94.34 & 28.16 \\
UFIL & 3.04 & 0.16 & 0.82 & 0.10 & 0.13 \\
Growth (\%) & -- & $(94.57)$ & 398.76 & $(87.61)$ & 33.29 \\
\hline
\end{tabular}

Source: Author's calculation using the different issues of Annual Report of LankaBangla Investment Ltd., Prime Finance Capital Management Ltd., IDLC Investment Ltd. and Uttara Finance and Investment Ltd.

Note: US \$1 = BDT 78

\subsection{Issue Management Fees}

Table: 9 showed growth pattern of issue management fees of selected merchant banks. It is observed from the table that issue management fees were highest in LBIL in year 2015 i.e Tk. 23.43 million. The growth percentage of PFCML is highest in year 2014 is $104.01 \% \%$. In 2014 growth percentage of LBIL, PFCML, and IDLCIL is $75.93 \%, 104.01 \%$ and $171.43 \%$ respectively. 
Table 9. Issue Management Fees

BDT Million

\begin{tabular}{lrrrrr}
\hline Company & 2011 & 2012 & 2013 & 2014 & 2015 \\
\hline LBIL & 5.82 & 8.91 & 3.86 & 6.79 & 23.43 \\
Growth (\%) & -- & 53.10 & $(56.68)$ & 75.93 & 245.02 \\
PFCML & 30.36 & 6.08 & 1.80 & 3.67 & 1.91 \\
Growth (\%) & -- & $(79.95)$ & $(70.42)$ & 104.01 & $(47.87)$ \\
IDLCIL & 2.00 & 0.30 & 3.50 & 9.50 & 4.61 \\
Growth (\%) & -- & $(85.00)$ & 1066.67 & 171.43 & $(51.47)$ \\
UFIL & 0 & 1.01 & 0 & 0 & 0 \\
Growth (\%) & -- & 0 & 0 & 0 & 0 \\
\hline
\end{tabular}

Source: Author's calculation using the different issues of Annual Report of LankaBangla Investment Ltd., Prime Finance Capital Management Ltd., IDLC Investment Ltd. and Uttara Finance and Investment Ltd.

Note: US \$1 = BDT 78

\subsection{Corporate Advisory Fees}

It is observed from the Table: 10 that corporate advisory fees of IDLCIL were high in year 2013 that is $48.56 \%$. In most of the years corporate advisory fees decreased from previous year of all selected merchant banks. On the other hand IDLCIL experienced the highest corporate advisory fees in year 2015 that is TK.12.12 million.

Table 10. Corporate Advisory Fees

BDT Million

\begin{tabular}{lrrrrr}
\hline Company Name & 2011 & 2012 & 2013 & 2014 & 2015 \\
\hline LBIL & 0.10 & 3.56 & 1.56 & 4.65 & 3.27 \\
Growth (\%) & -- & 3460.00 & $(56.18)$ & 198.08 & $(29.60)$ \\
PFCML & 0.10 & 0.52 & 1.50 & 1.39 & 1.25 \\
Growth (\%) & -- & 415.00 & 191.26 & $(6.75)$ & $(10.63)$ \\
IDLCIL & 9.95 & 9.10 & 13.52 & 10.45 & 12.17 \\
Growth (\%) & -- & $(8.53)$ & 48.56 & $(22.71)$ & 16.46 \\
UFIL & N/A & N/A & N/A & N/A & N/A \\
Growth (\%) & -- & 0 & 0 & 0 & 0 \\
\hline
\end{tabular}




\section{Macrothink}

Source: Author's calculation using the different issues of Annual Report of LankaBangla Investment Ltd., Prime Finance Capital Management Ltd., IDLC Investment Ltd. and Uttara Finance and Investment Ltd.

Note: US $\$ 1=$ BDT 78

Note: N/A not available

\subsection{Underwriting Commission}

Table: 11 showed growth pattern of underwriting commission of selected merchant banks in Bangladesh. The table reflected that growth of underwriting commission of IDLCIL showed upward sloping every year and it was highest in year 2014 that is TK.2.76 million. Underwriting commission of LBIL decreased from year 2011 to year 2013 but after that it increased tremendously in year 2014 and year 2015.

Table 11. Underwriting Commission

BDT Million

\begin{tabular}{lrrrrr}
\hline Company & 2011 & 2012 & 2013 & 2014 & 2015 \\
\hline LBIL & 1.53 & 1.44 & 0.34 & 1.28 & 1.47 \\
Growth (\%) & -- & $(5.62)$ & $(76.19)$ & 274.45 & 14.38 \\
PFCML & 12.30 & 2.62 & 1.94 & 1.77 & 0.49 \\
Growth (\%) & -- & $(78.68)$ & $(26.09)$ & $(8.49)$ & $(71.92)$ \\
IDLCIL & 0 & 0.75 & 0.92 & 2.76 & 1.28 \\
Growth (\%) & -- & 0 & 23.26 & 200.00 & $(53.62)$ \\
UFIL & 0.04 & 0 & 0 & 0.30 & 0 \\
Growth (\%) & -- & 0 & 0 & 0 & 0 \\
\hline
\end{tabular}

Source: Author's calculation using the different issues of Annual Report of LankaBangla Investment Ltd., Prime Finance Capital Management Ltd., IDLC Investment Ltd. and Uttara Finance and Investment Ltd.

Note: US \$1 = BDT 78

\subsection{Trend Equation of Selected Merchant Banks}

Table: 12 showed the summary of trend equation and $r^{2}$ of Investment in Securities of selected merchant banks. It is reflected from the table that trend equation of all the selected merchant banks are positive and Goodness of fit of all the equations are high i.e. more than 0.80 except LBIL and PFCML. 
Table 12. Trend Equation and $\mathrm{r}^{2}$ of Investment in Securities

\begin{tabular}{lcc}
\hline Company & \multicolumn{1}{c}{$\mathrm{Yc}=\mathrm{a}+\mathrm{bx}$} & $\mathrm{r} 2$ \\
\hline LBIL & $\mathrm{Yc}=157.35+38.29 \mathrm{x}$ & 0.28 \\
PFCML & $\mathrm{Yc}=312.29+6.35 \mathrm{x}$ & 0.03 \\
IDLCIL & $\mathrm{Yc}=251.09+94.31 \mathrm{x}$ & 0.80 \\
UFIL & $\mathrm{Yc}=343.37+218.35 \mathrm{x}$ & 0.80 \\
\hline
\end{tabular}

Table: 13 showed the summary of trend equation and $r^{2}$ of margin loan to clients of selected merchant banks. It is imitated from the table that trend equations of all the selected merchant banks are positive except LBIL. Goodness of fit of IDLCIL and UFIL is high i.e. more than 0.80 .

Table 13. Trend Equation and $\mathrm{r}^{2}$ of Margin Loan to Clients

\begin{tabular}{lcc}
\hline Company & \multicolumn{1}{c}{$\mathrm{Yc}=\mathrm{a}+\mathrm{bx}$} & $\mathrm{r} 2$ \\
\hline LBIL & $\mathrm{Yc}=410.82+(60.15) \mathrm{x}$ & 0.06 \\
PFCML & $\mathrm{Yc}=5021.08+528.11 \mathrm{x}$ & 0.12 \\
IDLCIL & $\mathrm{Yc}=12.76+9.64 \mathrm{x}$ & 0.80 \\
UFIL & $\mathrm{Yc}=1617.33+167.42 \mathrm{x}$ & 0.97 \\
\hline
\end{tabular}

Table-14 shows the summary of trend equation and $r^{2}$ of brokerage commission of selected merchant banks. It is replicated from the table that trend equations of all the selected merchant banks are positive except UFIL. Goodness of fit of PFCML and UFIL is more than 0.50 except LBIL and IDLCIL.

Table 14. Trend Equation and $\mathrm{r}^{2}$ of Brokerage Commission

\begin{tabular}{lcc}
\hline Company & \multicolumn{1}{c}{$\mathrm{Yc}=\mathrm{a}+\mathrm{bx}$} & $\mathrm{r} 2$ \\
\hline LBIL & $\mathrm{Yc}=589.42+-19.52 \mathrm{x}$ & 0.06 \\
PFCML & $\mathrm{Yc}=1.75+1.46 \mathrm{x}$ & 0.53 \\
IDLCIL & $\mathrm{Yc}=184.55+4.13 \mathrm{x}$ & 0.05 \\
UFIL & $\mathrm{Yc}=31.70+(8.17) \mathrm{x}$ & 0.73 \\
\hline
\end{tabular}

Table: 15 shows the summary of trend equation and $r^{2}$ of capital gain/loss from sale of securities of selected merchant banks It is simulated from the table that trend equations of all the selected banks are positive except IDLCIL. Goodness of fit of all the selected banks is low.

Table 15. Trend Equation and $\mathrm{r}^{2}$ of Capital Gain/Loss from Sale of Securities

\begin{tabular}{lcc}
\hline Company & \multicolumn{1}{c}{$\mathrm{Yc}=\mathrm{a}+\mathrm{bx}$} & $\mathrm{r} 2$ \\
\hline LBIL & $\mathrm{Yc}=112+13.12 \mathrm{x}$ & 0.02 \\
PFCML & $\mathrm{Yc}=57.80+5.90 \mathrm{x}$ & 0.05 \\
IDLCIL & $\mathrm{Yc}=(16.88)+18.16 \mathrm{x}$ & 0.33 \\
UFIL & $\mathrm{Yc}=48.49+13.42 \mathrm{x}$ & 0.27 \\
\hline
\end{tabular}




\section{Macrothink}

Table: 16 showed the summary of trend equation and $r^{2}$ of interest income from merchant bank of selected merchant banks in Bangladesh. It is reflected from the table that trend equation of all the selected merchant banks are positive and Goodness of fit of all the equations are high i.e. more than 0.50 except PFCML and IDLCIL.

Table 16. Trend Equation and $\mathrm{r}^{2}$ of Interest Income from Merchant Bank

\begin{tabular}{lcc}
\hline \multicolumn{1}{c}{ Company } & \multicolumn{1}{c}{$\mathrm{Yc}=\mathrm{a}+\mathrm{bx}$} & $\mathrm{r} 2$ \\
\hline LBIL & $\mathrm{Yc}=437.48+(167.43) \mathrm{x}$ & 0.90 \\
PFCML & $\mathrm{Yc}=297.12+(46.88) \mathrm{x}$ & 0.41 \\
IDLCIL & $\mathrm{Yc}=82.81+0.92 \mathrm{x}$ & 0.01 \\
UFIL & $\mathrm{Yc}=136.35+(31.01) \mathrm{x}$ & 0.56 \\
\hline
\end{tabular}

Table: 17 showed the summary of trend equation and $r^{2}$ of portfolio management services investment of fund of selected merchant bank. It is replicated from the table that trend equations of all the selected merchant banks are negative except IDLCIL. Goodness of fit of all the selected merchant banks are high i.e. more than 0.80 except IDLCIL.

Table 17. Trend Equation and $r^{2}$ of Portfolio Management Services

\begin{tabular}{lcc}
\hline Company & \multicolumn{1}{c}{$\mathrm{Yc}=\mathrm{a}+\mathrm{bx}$} & $\mathrm{r} 2$ \\
\hline LBIL & $\mathrm{Yc}=59.39+(24.72) \mathrm{x}$ & 0.84 \\
PFCML & $\mathrm{Yc}=92.34+(19.29) \mathrm{x}$ & 0.81 \\
IDLCIL & $\mathrm{Yc}=69.88+1.37 \mathrm{x}$ & 0.02 \\
UFIL & $\mathrm{Yc}=20.08+(4.93) \mathrm{x}$ & 0.87 \\
\hline
\end{tabular}

Table: 18 showed the summary of trend equation and $r^{2}$ of settlement and transaction fees of selected merchant banks. It is observed from the table that except UFIL, trend equation of the selected merchant banks is positive.

Table 18. Trend Equation and $\mathrm{r}^{2}$ of Settlement and Transaction Fees

\begin{tabular}{lcc}
\hline Company & \multicolumn{1}{c}{$\mathrm{Yc}=\mathrm{a}+\mathrm{bx}$} & $\mathrm{r} 2$ \\
\hline LBIL & $\mathrm{Yc}=33.99+2.16 \mathrm{x}$ & 0.43 \\
PFCML & $\mathrm{Yc}=0.0006+0.0003 \mathrm{x}$ & 0.13 \\
IDLCIL & $\mathrm{Yc}=23.02+1,353,589 \mathrm{x}$ & 0.06 \\
UFIL & $\mathrm{Yc}=4.88+(4.58) \mathrm{x}$ & 0.50 \\
\hline
\end{tabular}

Table-19 showed the summary of trend equation and $r^{2}$ of documentation fees of selected merchant banks in Bangladesh. It is revealed from the table that trend equation of LBIL. IDLCIL are positive and goodness of fit of IDLCIL and PFCML is very high i.e. more than 0.90 . 
Table 19. Trend Equation and $r^{2}$ of Documentation Fees

\begin{tabular}{lcc}
\hline Company & $\mathrm{Yc}=\mathrm{a}+\mathrm{bx}$ & $\mathrm{r} 2$ \\
\hline LBIL & $\mathrm{Yc}=0.04+0.003 \mathrm{x}$ & 0.02 \\
PFCML & $\mathrm{Yc}=0.020+(0.010) \mathrm{x}$ & 0.94 \\
IDLCIL & $\mathrm{Yc}=0.04+0.011 \mathrm{x}$ & 0.91 \\
UFIL & $\mathrm{Yc}=0.85+(0.59) \mathrm{x}$ & 0.54 \\
\hline
\end{tabular}

Table: 20 showed the summary of trend equation and $r^{2}$ of issue management fees of selected merchant banks. It is reflected from the table that trend equation of LBIL and IDLCIL is positive and Goodness of fit of all the equations are high except UFIL.

Table 20. Trend Equation and $\mathrm{r}^{2}$ of Issue Management Fees

\begin{tabular}{lcc}
\hline Company & \multicolumn{1}{c}{$\mathrm{Yc}=\mathrm{a}+\mathrm{bx}$} & $\mathrm{r} 2$ \\
\hline LBIL & $\mathrm{Yc}=9.76+3.31 \mathrm{x}$ & 0.44 \\
PFCML & $\mathrm{Yc}=8.77+(5.92) \mathrm{x}$ & 0.59 \\
IDLCIL & $\mathrm{Yc}=3.98+1.44 \mathrm{x}$ & 0.43 \\
UFIL & $\mathrm{Yc}=0.20+(0.10) \mathrm{x}$ & 0.13 \\
\hline
\end{tabular}

Table-21 showed the summary of trend equation and $r^{2}$ of corporate advisory fees of selected merchant banks. It is exposed from the table that trend equation of all selected merchant banks are positive and goodness of fit of PFCML is high i.e. 0.67.

Table 21. Trend Equation and $\mathrm{r}^{2}$ of Corporate Advisory Fees

\begin{tabular}{lcc}
\hline Company & $\mathrm{Yc}=\mathrm{a}+\mathrm{bx}$ & $\mathrm{r} 2$ \\
\hline LBIL & $\mathrm{Yc}=2.63+0.07 \mathrm{x}$ & 0.43 \\
PFCML & $\mathrm{Yc}=0.94+0.32 \mathrm{x}$ & 0.67 \\
IDLCIL & $\mathrm{Yc}=11.04+0.58 \mathrm{x}$ & 0.26 \\
UFIL & $\mathrm{N} / \mathrm{A}$ & $\mathrm{N} / \mathrm{A}$ \\
\hline
\end{tabular}

Table-22 showed the summary of trend equation and $r^{2}$ of underwriting commission of selected merchant banks. It is exposed from the table that trend equations of IDLCIL and UFIL are positive and goodness of fit of PFCML and IDLCIL is more than 0.50.

Table 22. Trend Equation and $\mathrm{r}^{2}$ of Underwriting Commission

\begin{tabular}{lcc}
\hline Company & \multicolumn{1}{c}{$\mathrm{Yc}=\mathrm{a}+\mathrm{bx}$} & \\
\hline LBIL & $\mathrm{Yc}=1.22+(0.03) \mathrm{x}$ & 0.01 \\
PFCML & $\mathrm{Yc}=3.82+(2.44) \mathrm{x}$ & 0.65 \\
IDLCIL & $\mathrm{Yc}=1.14+0.46 \mathrm{x}$ & 0.50 \\
UFIL & $\mathrm{Yc}=0.07+0.02 \mathrm{x}$ & 0.07 \\
\hline
\end{tabular}




\section{Findings and Conclusion}

The concept of merchant banking is not much familiar among mass people but in developed countries it becomes a prime mover of economic development. It contributes greatly for the development of more authenticated and structured capital market and helps to form a more stable economy. Every year many potential companies are funded and discovered by merchant banks. Their specialized investment techniques help many potential companies turn into business conglomerate within a decade from small sole proprietorships.

In a more developed market, institutional investors such as merchant banks, commercial banks, insurance companies, are major traders of securities. Merchant banks are considered as the original banking institutes which have been started during the middle ages. With the evolution of economic terms and practices, merchant banking services were differentiated from ordinary banks which provide services to common people as well as organizations, but merchant banking serves a number of needs and requirements of organizations and businesses. The fact that, merchant banks are the wholesale banks specifies the use of these banks for some important purposes. Today, merchant banks are regarded as the banks of corporate house and organizations.

The selected merchant banks create employment opportunities for the country. It has been observed that investment in securities, brokerage commission, underwriting commission, margin loan to clients, corporate advisory services, issue management fees, portfolio management fees, documentation fees, settlement and transaction fees of the selected merchant banks have increased from the previous year during 2011-2015. It is also reflected from the analysis that the margin loan to client, capital gain from securities of the selected merchant banks is relatively high during 2011-2015. It indicates the profitability of all the selected merchant banks is quite satisfactory. The study revealed that every year brokerage commission, settlement and transaction fees, issue management fees, corporate advisory services of the selected merchant banks increased at a decreasing trend which indicated the selected merchant banks should focus more and employ efficient manpower to this sector.

Seven trend equations have been tested for different activities of the merchant banks. Among them the trend value of investment in securities and corporate advisory fees is positive of all selected merchant banks. Square of correlation coefficient $\left(r^{2}\right)$ has also been tested for all trend equations. The $r^{2}$ of documentation fees and portfolio management services is more than 0.5. It indicates the prospect of merchant banks in Bangladesh is bright.

The growth percentage of portfolio management services, settlement and transaction fees of all the selected merchant banks were very low and fluctuating. In order to increase activities and income these merchant banks need to increase their service income.

From the series of our analysis it is reflected that every year corporate advisory services increases in a very unstable way and interest income merchant banks activities decrease in an alarming rate which should be highly focused and resolved by the sleeted merchant banks in Bangladesh.

It has been identified that although almost every year's investment in securities of selected 
merchant banks have increased from the previous year, but the growth rate of brokerage commission and underwriting commission is not satisfactory. So it should try to increase the growth rate.

The authors are quite optimistic that if the given suggestions of this paper are implemented then the merchant banks sector will be able to overcome its present problems and may contribute in the rapid development of the economy of Bangladesh.

\section{Reference}

Bauer, P.W., Berger, A.N., Ferrier, G.D., \& Humphrey, D.B. (1998). Consistency Conditions for Regulatory Analysis of Financial Institutions: A Comparison of Frontier Efficiency Methods. Journal of Economics and Business 50(2), 85-114. https://doi.org/10.1016/S0148-6195(97)00072-6

Berger, A.N., \& D.B. Humphrey. (1997). Efficiency of Financial Institutions: International Survey and Directions for Future Research. European Journal of Operational Research, 98(2). https://doi.org/10.1016/S0377-2217(96)00342-6

Dyson, R.G., Allen ,R., Camanho, A.S., Podinovski, V.V., Sarrico, C.S., \& Shale, E.A. (2001). Pitfalls and Protocols in DEA. European Journal of Operational Research, 132, 245-259. https://doi.org/10.1016/S0377-2217(00)00149-1

IDLC Investment Ltd. (2011-2015). Annual Report.

Keyurkumar, D., \& M, Nayak.(2015). Does Public Sector Merchant Banks Require Pills to Survive? Indian journal of applied research, 5(1).

Lanka Bangla Investment Ltd. (2011-2015). Annual Report.

McAllister, P.H., \& McManus, D.A. (1993). Resolving the Scale Efficiencies Puzzle in Banking. Journal of Banking and Finance, 17(2-3), 389-405. https://doi.org/10.1016/0378-4266(93)90039-G

Marshall, John F., \& M. E. Ellis. (1994). Investment Banking and Brokerage. Probus Publishing.

Prime Finance Capital Management Ltd. (2011-2015). Annual Report.

R., Dutch., A. Charnes, \& W.W. Cooper. (1984). Some Models for Estimating Technical and Scale Inefficiencies in Data Envelopment Analysis. Journal of Management Science, 30(9), 1078-1092. https://doi.org/10.1287/mnsc.30.9.1078

Sealey, C., \& J.T. Lindley. (1977). Inputs, Outputs and A Theory of Production and Cost at Depository Financial Institutions. Journal of Finance, 32(4), 1251-1266. https://doi.org/10.1111/j.1540-6261.1977.tb03324.x

Shreyas B. S. (2014). Merchant Banking Past and Present: Indian Scenario. The International Journal of Business \& Management, 2(10). 
Singh, A. (2009) Merchant Banking - Factors Determining its Shape in India. Indian Journal of finance, $3(5)$.

Sufian, F., Zulkhibri, M., \& Majid, A. (2007). The efficiency of merchant banks and finance companies in an emerging market: Determinants and Policy issues. Business, finance \& economics in emerging economies, 2(1).

Uttara Finance and Investment Ltd. (2011-2015). Annual Report. 